\title{
Student-Generated Podcasting for Learning and Assessment in Undergraduate History
}

\author{
Dr Angela Byrne \\ University of Greenwich
}

\begin{abstract}
This case study reflects on the implementation and outcomes of the first use of podcasting in learning and assessment on an undergraduate History course in the Department of History, Politics and Social Sciences at the University of Greenwich. It describes how the podcast formed part of a holistic series of summative and formative assessments intended to foster independent learning and transferable research and presentation skills, and to diversify the range of assessments required by students within the department. It goes on to reflect on the implementation, outcomes, advantages and limitations of using podcasting as a means of assessment for undergraduate History.
\end{abstract}

\section{Introduction}

In 2014-15, podcasting was adopted as a means of learning and assessment on the course 'Global Exploration from Columbus to Scott's Antarctic', offered to second-year undergraduate students in the Department of History, Politics and Social Sciences (HPSS) at the University of Greenwich. This course was offered for the first time in 2014-15, presenting an opportunity to experiment with diversifying the range of assessments required of HPSS students. The podcast was selected as an alternative to traditional in-class presentations, with the objective of providing students with enhanced opportunities to produce assessed podcasts based on their own original, historical research on a topic of their choice. The podcasts received both formative peer feedback and summative lecturer feedback. This case study reflects on student and lecturer experiences of the initiative, following the delivery of the course and after the completion of internal and external marking procedures.

\section{Pedagogical and disciplinary concerns}

As a discipline, History has, in recent years, increasingly come to emphasise the wider application of research and the communication of research findings, via technology and social media, to the public and to non-academic audiences (Grove, 2009). The subject area also retains its strong emphasis on the importance and utility of public lectures (outreach) and presentations. The podcasting project and assessment enhance the student employability skillset in various ways: through production of a portable artefact and applied skills; by improving student digital literacy (introducing them to technological skills and software which most of them have not previously used); by assisting the development of their presentation and communication skills (preparation, scripting, timing, delivery); by cultivating engagement through diversity of assessment. At all educational levels, the creation of podcasts is recognised as helping students "to do research, to communicate in print, to speak effectively and grab attention with sound" (Selingo, 2006).

The assessment map of this course attempted to integrate two learning activities that are considered meaningful and dynamic - the creation of a summative podcast and a related, formative, peer review exercise (see Table 1). Podcasting has been specifically highlighted 
as a means 'to get students involved in activities that are meaningful, integrative, valuebased, challenging, and active' (Tinker et al, 2007, p.19). Similarly, peer assessment is considered conducive to 'meaningful learning' (Keppell et al, 2006, p.453) and to fostering ownership, autonomy, transferable skills, and deep learning (Vickerman, 2009, p.222).

The student-generated content was envisaged as being usable in peer-instruction. Rachtham and Zhang (2006) demonstrate that the most profound pedagogical value of podcasting lies in the collaborative opportunities it offers to learners. Downward et al (2008) also find that 'the production of the podcast is incremental, revisionist and is developed in multiple learning spaces' (p.66). The podcast peer review gives students the opportunity to reflect on their own practice and that of their peers - an essential part of the process of experiential learning (Fry et al, 2009, pp.15-16). Finally, the peer review aspect of the exercise speaks to the essential role of the audience in the preparation and delivery of any podcast, with the added benefit of providing an alternative to the individual-centric nature of written assessments (Boud et al, 1999, p. 413).

Experiential learning is a key factor in the delivery of the 'Global Exploration' course, which includes a number of relevant fieldtrips and museum visits. These learning opportunities complement the podcast assessment and fits Kolb's model of the experiential learning cycle (1984). Students are first given the opportunity to become freely involved in new experiences (through designing a podcast on a topic of their own choosing); they are then given an opportunity to reflect, through the podcast peer-review process detailed below; finally, they develop their initial ideas into a 4000-word research essay that presents the possibility for independent research and the development of new understanding (Table 1).

\section{Context}

In 2014-15, forty-seven second-year HPSS students enrolled on the 30-credit course 'Global Exploration from Columbus to Scott's Antarctic.' The majority were single-honours History students, with a minority taking combinations of History with English, Sociology, or Politics.

The course requires students to produce a ten-minute podcast as one of four assessments, one of which is formative and three of which are summative (see Table 1). The podcast topic should relate to the topic of the student's end-of-year research essay and is worth $20 \%$ of the student's overall grade for the course.

\begin{tabular}{|l|l|l|l|l|}
\hline $\begin{array}{l}\text { Method of } \\
\text { assessment }\end{array}$ & Book review & Podcast & Podcast review & Research essay \\
\hline Word length & 1500 & NA & 350 & 4000 \\
\hline $\begin{array}{l}\text { Proportion of } \\
\text { overall grade }\end{array}$ & $20 \%$ & $20 \%$ & NA: Formative & $60 \%$ \\
\hline $\begin{array}{l}\text { Outline } \\
\text { details }\end{array}$ & $\begin{array}{l}\text { A critical review of } \\
\text { a published book } \\
\text { on the history of } \\
\text { exploration. }\end{array}$ & $\begin{array}{l}\text { A ten-minute } \\
\text { podcast related to } \\
\text { research essay } \\
\text { topic, uploaded to } \\
\text { the Moodle site. }\end{array}$ & $\begin{array}{l}\text { Peer-review of } \\
\text { another student's } \\
\text { podcast; review } \\
\text { to be shared on } \\
\text { Moodle. }\end{array}$ & $\begin{array}{l}\text { A research essay on } \\
\text { a topic relevant to the } \\
\text { history of exploration, } \\
\text { pre-approved by } \\
\text { seminar leader. }\end{array}$ \\
\hline
\end{tabular}

Table 1: Assessment map for 'Global Exploration from Columbus to Scott's Antarctic.' 


\section{Task structure and process}

Students were offered two ninety-minute group tutorials on how to produce a podcast, in advance of which they were requested to plan their podcast using a proforma distributed via Moodle. The tutorials demonstrated the use of open-source Audacity software on University PCs and students were provided with a step-by-step guide to planning, recording, editing and uploading their podcasts and transcripts. Most students chose to use University facilities to produce their submissions; the others elected to use their personal laptops or smartphones.

Students were instructed to save their podcasts in a compatible file format and upload them to the course Virtual Learning Environment, in this case a Moodle 'Workshop' drop-box set up by the lecturer. They were also required to submit a referenced transcript through Turnitin. The podcast submissions were paired, using Moodle's automated pairing facility, and the students were given two weeks to peer-review their partner's submission, in 350 words and within a set rubric, addressing the following areas:

1. Clarity of voice and quality of recording;

2. How well the content held their interest for the full ten minutes;

3. Accuracy of information and quality of analysis;

4. How well the podcast explained the topic;

5. Overall comments.

Grades were awarded to the individual podcasts according to a previously-distributed rubric, with equal weighting given to structure, research, communication and planning. The standard of podcasts submitted for assessment was very high, demonstrating excellent engagement with a means of assessment that was new to most of the students. Those achieving grades in the first and upper-second ranges went to considerable effort with sound effects (for example, demonstrated high production values - sound quality and clarity), combined with creative use of primary source material (for example, created mock interviews with celebrated explorers) and concision in delivery of key points and information. The distribution of class marks across the cohort was as follows:

\begin{tabular}{|l|l|}
\hline Grade band & Number of students \\
\hline First class & 11 \\
\hline Upper second & 20 \\
\hline Lower second & 9 \\
\hline Third & 3 \\
\hline Fail & 3 \\
\hline Non-submission & 1 \\
\hline Total & 47 \\
\hline
\end{tabular}

Table 2: Distribution of class marks for podcast assignment.

This compares favourably with the other two summative assessments the course requires (book review and research essay), with more students achieving first-class marks (see Table 3). 


\begin{tabular}{|l|l|l|}
\hline Grade band & Number of students \\
\hline & Book review & Research essay \\
\hline First class & 1 & 6 \\
\hline Upper second & 26 & 21 \\
\hline Lower second & 17 & 12 \\
\hline Third & 3 & 4 \\
\hline Fail & - & 2 \\
\hline Non-submission & - & 2 \\
\hline Totals & 47 & 47 \\
\hline
\end{tabular}

Table 3: Distribution of class marks for book review and research essay.

Finally, the individual peer reviews were awarded marks out of ten in Moodle, along with brief comments on each review's usefulness. This was intended to emphasise the level of responsibility attached to peer review (Dochy et al, 1999, p.338) and the importance of constructive feedback.

\section{Outcomes}

Students unfamiliar with audio recording equipment and software initially expressed concerns about their technical abilities, but most of the students' fears in this regard were allayed by the provision two ninety-minute group tutorials in the University computer lab, a detailed handout of instructions and some follow-up one-to-one tutorials. The Audacity software is especially straightforward to use and many students reported in conversation that, in the end, planning and scripting their podcast presented a bigger challenge than the unfamiliarity of the software. This concurs with the experiences described by Historical Geography students in Kemp et al's study (2013, p.6).

A technical challenge emerged in the course of the peer-review exercise and grading - a small number of students had failed to save their podcasts in the required compatible format. The issue was soon resolved by some lecturer mediation between student pairs, mostly conducted by email. This technical issue was crucial, as the 'Workshop' facility in Moodle functions on the premise that all participants progress to the next stage of the exercise before a predetermined date and time. After this point, no new uploads can be accepted, so any delay in uploading podcasts or providing the peer-review can be detrimental to the student experience and to their gaining, and giving, peer feedback.

\section{Evaluation}

\section{Student feedback}

At the outset it should be noted that a switch to an electronic system saw low feedback rates in this academic year. Of a cohort of forty-seven students, only seventeen provided feedback. On the whole, however, student feedback about being presented with a new, unfamiliar means of assessment was positive. End-of-year course feedback indicated that students valued the opportunity to learn a new skill that could have a practical application in other courses or during their final year:

"Interesting new methods of assessment. Independent research tasks are always good to learn skills relevant for dissertation." 
Students themselves expressed some surprise at how much they enjoyed the process of planning and producing a podcast - something they had not initially expected. They valued the originality of the podcast as a means of assessment:

"I really enjoyed making the podcast[.] I think the whole idea of using different technologies to engage people is a really good idea."

"I feel the course is exceptionally well taught and very entertaining to learn. I feel pushed beyond the areas i [sic] would usually study and the unique assignments such as the podcast was interesting and ensured the course did not feel repetitive."

It should be noted that a minority of the student feedback forms communicated an instrumentalist attitude that tends to favour familiar forms of assessment, with two of the seventeen respondents commenting:

"Not too keen on the podcast would rather do another essay or presentation."

"Although $i$ [sic] enjoyed the inclusion of the podcast in the course $i$ [sic] feel that many other students were unhappy with it. I feel they felt that the podcast was unnecessary."

On balance, the majority view appears to have been that the podcast was valuable simply because it was an unusual form of assessment. This may indicate a lack of appreciation of the full value of this transferable skill. It cannot be said whether this is the effect of a disciplinary 'blinker' or of another factor.

\section{Benefits to students}

There are arguments for the value of technology in higher education and for the autonomy and independent learning it encourages (Powell and Robson, 2014, p.327). Furthermore, Dale and Hassanien have suggested that podcasting "can be effective in enhancing student engagement and reflection [...] a shared learning experience where conceptual thoughts and ideas can be created spontaneously [...] lead[ing] to a more progressive and reflective learning experience." (2008, p.47).

The peer feedback element - as opposed to peer assessment or simple grading - plays an important role in student development of "an active role in the management of their own learning", as a form of "self-regulated learning" and as a means by which to improve their own self-assessment (Liu and Carless, 2006, pp.280-1). The peer feedback was, on the whole, overwhelmingly positive and constructive. Many of the peer reviews emphasised how much students enjoyed having the opportunity to hear each other's podcasts: "clever and engaging"; "exceptionally interesting [...] good enough to pass as a [sic] academic podcast"; "refreshing and intriguing". The overwhelming positivity of the feedback may have been owing in part to the small size of the cohort - a reluctance to criticise a classmate. Some constructive comments were made on presentational factors, like audibility and clarity of voice.

\section{Benefits to lecturer}

As pointed out by Kemp et al (2013, p.4), one practical advantage to the lecturer is the ability to listen back to the podcast as often as necessary or desired - impossible with a traditional in-class presentation - and a reduction in student nervousness. Another clear advantage was the salvaging of valuable classroom time that would otherwise have been devoted to inclass presentations. These benefits outweighed the extra time spent assisting a small number of students with technical difficulties. 


\section{Conclusion}

This use of podcasting as a means of assessment on a second-year core History course resulted in a range of outcomes. The student skillset is broadened (through exposure to new software, techniques and requirements) and student learning and engagement with the subject matter are enhanced (through independent learning and exposure to others' ideas). As the podcast was to relate to the same topic as the end-of-year 4000-word research essay, students were encouraged to begin planning their research in good time (eight weeks before the essay deadline). Finally, the high level of student engagement was evident in the excellent marks achieved in the podcast assessment across the cohort (see Table 2).

This item of assessment has been retained, but some changes and improvements are under consideration. The peer review element may be improved with double rather than single reviews, to balance student tendencies to be over-positive or over-negative (Vickerman, p.224). Anonymous peer review was problematic in this instance, as, in a relatively small cohort, the podcast creator is easily identifiable. Consideration may also be given to removing the first item of assessment (book review), and replacing it with a podcast plan for peer review, to allow students an opportunity to improve their work and grade. Switching the podcast from an individual to a group exercise may also be considered, although Kemp et al (2013, p.4) note some student reservations in relation to the dynamics of group work.

Considerations for future implementation also include student expectations of the technological requirements of the course, as well as a minority instrumentalist attitude that tends to favour familiar forms of assessment. As noted above, one student feedback form stated that they would prefer to be assigned an essay or presentation. Diversifying the range of assessments across departments may have positive impacts in this regard.

Finally, the restriction of this sample of students to one department (HPSS) may limit the transferability of results to other departments or faculties, particularly those with a stronger technological focus.

\section{Reference list}

Boud, D., Cohen, R. and Sampson, J. (1999) 'Peer learning and assessment.' Assessment and Evaluation in Higher Education, 24(4), 413-26.

Dale, C. and Hassanien, A. (2008) 'Podcasting in tourism education.' Journal of Teaching in Travel Tourism, 7(3), 43-60.

Dochy, F., Segers, M. and Sluijsmans, D. (1999) 'The use of self-, peer- and co- assessment in higher education: a review.' Studies in Higher Education, 24(3), 331-50.

Downward, S., Livingstone, D., Lynch K. and Mount, N. (2008) 'Podcasts and locations.' In: Salmon, G. and Edirisingha, P. (eds.) Podcasting for Learning in Universities. Maidenhead: McGraw-Hill Education, 57-69.

Fry, H., Ketteridge, S. and Marshall, S. (eds.) (2009) A Handbook for Teaching and Learning in Higher Education: Enhancing Academic Practice, 3rd edition. Abingdon: Routledge.

Grove, T. (2009) 'New media and the challenges for public history.' Perspectives on History: 
The News Magazine of the American Historical Association, 47(5). Available at: www.historians.org/publications-and-directories/perspectives-on-history/may 2009/intersections-history-and-new-media/new-media-and-the-challenges-for-public-history (Accessed: 19 August 2015).

Kemp, J., Kotter, R., Mellor, A., Oosthoek, J.W. and White, C. (2013) 'Diversifying assessment across the 'two cultures': student-produced podcasts in Geography.' Planet, 27(1), 2-7.

Keppell, M., Au, E., Ma, A. and Chan, C. (2006) 'Peer learning and learning-oriented assessment in technology-enhanced environments.' Assessment and Evaluation in Higher Education, 31(4), 453-64.

Kolb, D. A. (1984) Experiential Learning: Experience as a Source of Learning and Development. New Jersey: Prentice Hall.

Liu, N.-F., and Carless, D. (2006) 'Peer feedback: the learning element of peer assessment.' Teaching in Higher Education, 11(3), 279-90.

Rachtham, P. and Zhang, X. (2006) 'Podcasting in academia - a new knowledge management paradigm within academic settings.' SIGMIS-CPR'06, April 13-15. Selingo, J. (2006) 'Students and teachers, from K to 12, hit the podcasts.' New York Times. Available at: http://www.nytimes.com/2006/01/25/technology/techspecial2/25podcast.html (Accessed: 19 August 2015).

Tinker, R., Horwitz, P., Bannasch, S., Staudt, C. and Vincent, T. (2007) 'Teacher uses of highly mobile technologies: probes and podcasts.' Educational Technology, 47(3), 16-20.

Vickerman, P. (2009) 'Student perspectives on formative peer assessment: an attempt to deepen learning?' Assessment and Evaluation in Higher Education, 34(2), 221-30. 